\title{
Instantaneous Marketing: An Analysis Of Processes To Make A Connection With Customers Through New Communications Technologies
}

Boonchai Hongcharu, Ph.D., National Institute of Development Administration, Thailand

\begin{abstract}
Marketers try to find ways to respond to the needs of their target customers through most modern communications technologies. As the means to communicate with customers change, marketers find it most convenient and cost effective to make direct contact with customers. This study explores the advanced media for marketers to make a two-way communication to interact in real time with their customers. Instantaneous marketing has revolutionized marketing communication. The exploitation of customer databases and the necessity to acquire more customer information have led the marketers to explore the ways to connect with customers more rapidly to bring differentiation to their products or services. Moreover, customers provide flow of information about various aspects of company's operations back to the company. Some companies still find it hard to cope with this enormous amount information in the fastest way possible. This study explores various communication technologies which help instantaneous marketing to come up with a model to explain the phenomenon. Implications for marketers will be provided to make us understand how we can make use of this information in practice.
\end{abstract}

Keywords: Instantaneous Marketing; Real Time Marketing; Customer Database; Customer Satisfaction; Social Media

\section{INTRODUCTION}

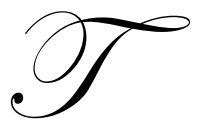

he digital age of communications technologies has resulted in a remarkable and unanticipated phenomenon in marketing. It has revolutionized the ways we connect with customers. The Internet has destroyed the time and space boundaries and enables manufacturers and customers to connect without any time limitation. We can now doing business twenty four hours a day, seven days a week or 24/7. In addition, the Internet also allows customers to contact their manufacturers across borders all around the globe, enabling marketers to trade their products anywhere they want. The remaining obstacles are regulatory and market factors which must be solved by human. The revolution has also resulted in a tremendous increase in productivity as we have never seen before.

Even though communications technologies have allowed such vast opportunities for marketers to connect broadly and conveniently with customers, both sides still do not exploit these digital opportunities to the most. The opportunities include the possibility for marketers to communicate instantaneously with their customers. It can be easily recognized that a lot of businesses still do not operate in such a way. Most are still waiting for their customers to contact them. Even worse, while some customers contact the marketers, the latter do not respond to them in real time. In this aspect, the businesses still have not adopted the marketing approach to take care of their customers. They do not realize what the new technologies can bring about.

This study intends to explore the instantaneous aspect of the digital communications technologies can benefit marketers in the ways they connect with their customers, as we realize that marketing would never be the same. 
Instantaneous marketing is defined as the ways customers and marketers connect with each other in real time or almost real time to respond to the needs of customers using customer databases and feedback through digital communications technologies. Instantaneous marketing gives both sides opportunities to deliver timely information resulting in a long time relationship between the two parties. These digital technologies generally include two-way interactive channels such as computer and telephone-based technologies e.g. emails, SMS, personal digital assistants, mobile phones, etc.

\section{RATIONALE FOR BUSINESSES TO ADOPT INSTANTANEOUS MARKETING}

\section{Customer perspectives}

As competition in the marketplace intensifies, it is natural that customers would choose the best choice of marketers who can constantly and instantly connect with them on their own conditions, through their preferred channel of communication and at their convenient time. In today's environment, customers have more choices to choose their desired methods to get contact from the marketers i.e. they have their own choices of products, prices, distribution channels and of course communication messages and media. They have their own timing for marketers. They will not want to be interrupted by the advertising messages forced to be received by marketers (Gilbreath, 2010). Marketers need to adjust themselves for these changes. Customers are getting used to the marketers who can solve their problems instantaneously.

\section{Competitor's pressures}

Almost all businesses in the capitalist society have competitors. The pressures from competitors are supposed to bring better quality, value and convenience for customers. While some companies are able to provide instantaneous service for customers, others are left with pressures to provide the same for their customers. Remote encounter has been a new means for marketers to serve their customers easily and conveniently (Shostack, 1985). If a computer software firm started to offer remote service to fix customer's problems via the Internet instantaneously, other companies followed suit to help their customers for fear that their customers would switch to other brands.

\section{Company's perspective}

It is a natural force for a decent company to improve and differentiate their products or services. At the same time, companies also have constant needs to lower their costs. They can achieve both differentiation and lower their costs at the same time (Gilbreath, 2010). However, several companies have been successful to exploit digital technologies for these purposes. In banking, the automated banking and later, Internet banking services have helped banks lower their costs to connect and provide instantaneous service for customers. In most cases, customers are the persons who execute their own transactions at any convenient time they want, while the banks save costs in establishing new branches and hiring more staff. In the airline industry, customers instantaneously make a reservation and bought an e-ticket by themselves in the airline's website. Thus, the airlines have saved their commission fee for travel agencies around 7-11\% of the ticketed price. Customers can then check in through the echeck-in system in the website and print their own boarding passes at any time they want about 48 hours before departure time. Then, they process their checked luggage by themselves at the airport. Again, airlines save money for hiring more staff and for renting check-in counters while customers save time queuing at the airport. The services have been more instantaneous than ever before.

\section{Technological pressures}

The changes in digital technology which allow companies to make use customers' information have led to the revolution which helps marketers to offer more customized products or other new products and services with instantaneous nature. The Internet has put pressures for many companies to offer instant help in their website. The requests of customers through the websites are linked instantly to a customer service representative who can help them at any time, while the companies save more cost offering this service than setting up a toll-free number. The advancement of database management system has also led to a customer relationship management (CRM) system 
which integrates customers' data into a computer screen where a customer service representative can see the customer's information and their past records and addresses or answer what the customers need in real-time (Fletcher, Wheeler \& Wright, 1990). In today's advancement of social media technology, Solis (2011) links the concept of Customer Relationship Management to the social network called Social CRM (sCRM). It focuses on the input of customers and the systems to connect with them by considering the influence of their stakeholders through social networks and public forums. The sCRM also allows feedback from the social network to flow into the database, providing outside intelligence for the company. Therefore, it is impossible for a company to stay put and satisfy with the traditional system to compete with their competitors and serve the needs of their customers. All these new digital technologies help the company come up with new products and services that bring new competitive advantage and put them in the forefront of technology to serve customers.

\section{SIGNIFICANT CONCEPTS OF INSTANTANEOUS MARKETING}

\section{Proactive marketing}

At present, marketers are not just sitting around waiting for the customers to request what they want but will proactively contact their customers and study what they need all the time. Instantaneous marketing allows marketers to communicate their customers proactively, as the better approach is to know what customer need before they mention it. With database of customers, marketers can start analyzing the information of their customers and decide to contact them first. One of the results is that the marketers know the needs of their customers before they request for anything. This will result in customer delight. That means marketers' performance will exceed the customer's expectation (Farris, Bendle, Pfeiffer \& Reibstein, 2010).

\section{Just-in-time delivery of information}

Manufacturers have long practiced the concept of just-in-time delivery of products to reduce costs. However, the just-in-time concept should also be applied to the delivery of information to customers. One of most serious obstacles was that there was no technology to provide such instant information until the Internet era. The Internet has provided the means for customers to search, find, check or track their own information instantaneously. With other interactive technologies such as mobile telephones, personal digital assistant, customers are expected to be contacted and informed at all time.

One of the applications of just-in-time delivery of information can be seen in the financial industry where the customers are provided with continuously flow of data which can help them make decisions for investment. The information is also provided on the personal finance level which allows customers to check their personal account and make transactions whenever and wherever they want to. This also applies to other industries. For instance, the National Basketball Association (NBA) installed a customer relationship management (CRM) system which provided a panoramic view of its customers and fans. The data can be transmitted to its headquarters to be analyzed instantaneously. (Songini, 2001). Marketers have applied the just-in-time delivery of information to provide data for their intermediaries to check the inventory of their goods and services so they can provide instant response for their customers. For instance, if a customer decides to order 10 tons of nails, the marketer needs to check several manufacturers to come up with an answer instantly his customers. Information technologies allow marketers to respond to what the customers request in no time, as the Enterprise Resource Planning (ERP) program connects databases of suppliers and their inventories to get a quick response for customers in real time. It has been a long time since the travel industry has applied the just-in-time delivery of information through customer reservation systems (CRS) to check the inventory of seats and rooms. Nowadays, customers can make their own reservations through the Internet and the marketers can update the inventory minute by minute.

\section{Information Sharing}

Instantaneous marketing allows marketers and customers to share the information about the products or services with other people, if the information is disseminated in the public forum such as websites, chat rooms and blogs, etc. The information allows other people who have never experienced with the products to listen to other people who have to (Gilbreath, 2010). It is the new format of word of mouth communication which is necessary for 
today's world of marketing communications (Kimmel, 2010). The information is helpful for prospects to decide to purchase the products or services. Information is very important for high involvement purchase decision as these products or services normally have high perceived risks. The information reduces the perceived risks and enables customers to make decision easily.

\section{Personalization}

According to Leboff (2011), the world of business has turned into two extremes: personalization and commodity. Marketers have a choice to provide a niche market with more personalized products, services or experience or serve a commodity for customers who concern about their cost and convenience. Personalization has emerged as there is no life time employment and there are people who can come together to provide a more specific, faster and custom-made offer for this group of niche market (Leboff, 2011). Marketers know how to offer instantaneous response for this group of customers as they intend to understand the specific needs of their customers. Marketers who can customize their offering to meet the needs of these customers more specifically can satisfy their customers easily. Personalization depends so much on the information customers provide the marketers. The information can help marketers make decision to help each individual differently.

\section{A MODEL OF INSTANTANEOUS MARKETING}

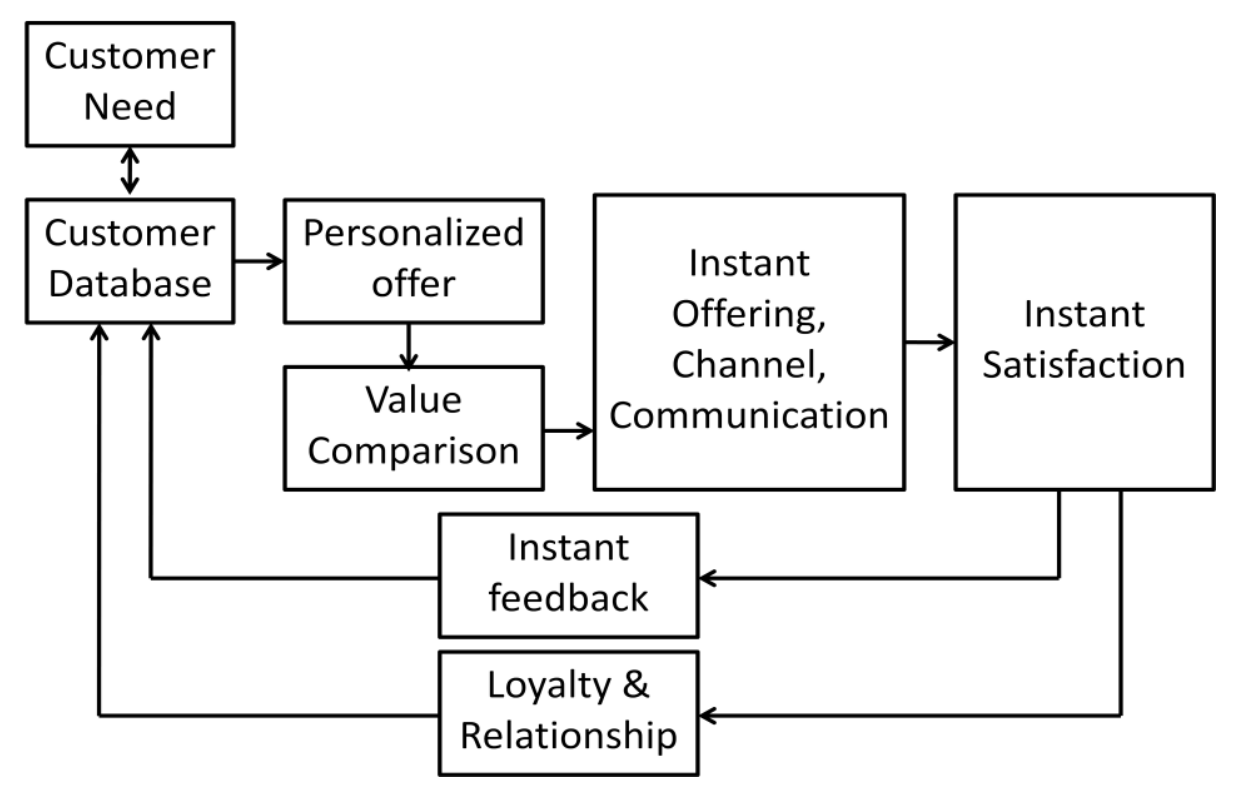

Figure 1: A Model of Instantaneous Marketing

To make a connection with customers instantaneously, companies and customers engage in a relationship which can be outlined as follows

\section{Customer Needs}

Customers generally recognize they have certain problems which need to be addressed. These needs that must be met immediately include needs for information to solve certain problems, to search for a product or service, etc.

In certain cases, customers really do not address their needs explicitly but it requires the capability of the marketers to understand them thoroughly. Thus, marketers have to depend on customer database analysis to be able 
to respond to those needs. This is different from the traditional Customer Decision Process Model where customers seek information by themselves. In this case, marketers need to engage in proactive marketing activities.

\section{Customer Database}

Customer database is essential for a company to market to customers in today's world. It allows the marketers to understand their customers even more thoroughly, using the past behavioral data of the customers who have had interactions with the company. Marketers are able to do data mining and understand the correlations of factors which affect the buying pattern of the customers. Modern corporations have their customer data shared across business units so they can service the customers better and faster (Ross, Weill \& Robertson, 2006). To make it possible for marketers to provide instantaneous marketing to customers, marketers must utilize the customer database to understand the speed in which the customers would like to be served. In several cases, customers have complained about the slow response of customer service representatives. The company can study the complaints through the database and improve the response time to satisfy the customers. At present, through proactive marketing, marketers need to be able to tell the needs of their customers through the customer databases, several industries are able to provide such a rapid response to customer. For instance, through previous purchase data of the customers, a pizza deliver firm is able to suggest and tell what the customers might want to order. A mobile phone operator is able to suggest the appropriate calling plan to a customer. The customer relationship management software would be able to provide the optimal alternative for an individual customer.

\section{Personalized offer}

In general, the offers provided by marketers through customer databases are a personalized one in which the customers would be more satisfied because the needs are met on an individual basis. It is more convenient to provide the personalized offer to customer using their own databases, as the marketers face fewer risks to waste their resources to guess what the customers want. In fact, the speed in which marketers provide to solve customers' problems may be different from one to another. In certain circumstances, instantaneous marketing may not be a significant factor for customers at all. Therefore, from customer databases, marketers may decide to devote their resources for instantaneous marketing to some but not to others. Through databases and personalization, it is possible for marketers to maximize the uses of their resources.

\section{Value Comparisons}

Customers normally compare details and information of all the offers of the company and its competitors. For instantaneous marketing, customers would weigh the benefits for getting the products or services in real time. The price for faster offering is generally much higher than the normal one. Therefore, it is necessary for customers to compare what the company offers with the competitor's one. The firm which can provide the personalized offer that fit most to the needs of customers is usually the winner.

\section{Instant Offering, Channel and Communication}

Companies invest in instantaneous marketing in three aspects: offering, channel and communication. The offers in which the company provides to customers are often real time. Most of the information providers such as software firms are the good examples of product offerings in real-time as customers can download the programs from the Internet instantly. Moreover, several companies decide to provide a hotline for customers to phone in and there are customer service representatives to solve the customer's problems. The examples are the Internet service providers which have their help desk 24 hours to help customers install programs, connect to the Internet and solve other computer-related problems. Mobile phone operators, airlines and hotel reservation hotlines and almost all the commercial banks also provide instant service for customers 24 hours.

Furthermore, companies start to invest more in technologies which allow customers to contact them at all time and in no time. In the old days, this would mean higher costs for marketers as more operating hours of traditional outlets means more costs. However, customers still find it very difficult to travel to the company's premises. Then, the companies offer telephone as a means to connect interactively with customers. Many have 
expanded this service to 24 hours as well. In today's environment, the company sets up its digital headquarters in the Internet so their customers can interact whenever and wherever they want. From there, the companies expand its channel to mobile phones, personal digital assistants and to social media websites, such as Facebook, Twitter, etc. All these new channels provide access to reach customers much more conveniently and it serves to get the instant feedback from customers.

The integration of channel of distribution and communication can be clearly witnessed. The development of digital technologies now allows "Disintermediation" whereby companies are attempting to eliminate the intermediaries and connect directly with their customers, saving enormous profit margins while they are able to provide personalized, real-time offer to their customers.

What companies can do certainly is to connect with their customers directly and instantly. Communication gives marketers a chance to get closer to their customers. With database management system, marketers can continuously contact and understand the customer's feedback which is delivered back to marketers through its own websites or other's websites allowing customers to express their opinion. The amount of such useful information can be enormous and the company must find ways to manage and make use of it as much as possible.

\section{Instant satisfaction}

Marketers have long been attempted to provide satisfaction to customers, which is the difference between customer's expectation and the actual performance of the offering (Farris, Bendle, Pfeiffer \& Reibstein, 2010). However, satisfaction can also be provided successfully by competitors and all market providers can give customers what they want to the levels they are satisfied. The pressures from competitors force marketers to solve the customer's problems instantly and give instant satisfaction to customers. At the same time, they have more time to provide the same results to additional customers. It is noticeable that marketers are investing in technologies and resources which can provide satisfaction to customers instantaneously.

\section{Instant feedback}

One of the benefits of instantaneous marketing is the marketers to receive feedback from customers in real time. Customer feedback is significant information for marketers and manufacturers to improve their products or services. Instant feedback helps the marketers alert themselves what they need to improve in all aspects. Through the company's own websites, hotlines, or blogs and chat rooms, etc., customers voice their opinions on products and services almost instantly after they experience with them, allowing this information to benefit the future customers or other participants who have never experienced before. In fact, the information of the feedback is not new for the corporations. Companies receive customer's complaints and compliments all the time. However, they have not received the information instantly to take actions to satisfy their customers. The information often came in too late for the corporations to fix the problems. Therefore, instant feedback is a full benefit that the companies should enjoy to improve their offerings to customers. When manufacturers design new fashion apparel, it is possible for them to get an instant feedback from customers by posting the apparel in the websites and let customers voice about it.

\section{Loyalty and Relationships}

By providing immediate response to customers, marketers are establishing a sense of continuous care with customers. In this sense, marketers are getting closer to customers and express concern in all aspects of business transactions. The interaction is necessary on a one-to-one relationship which is normally witnessed in the businessto-business transactions e.g. frequent sales calls by sales representatives. Digital technologies allow marketers to connect with the customers more frequently than before and to the level in which the companies have not been able to provide to their individual customers before and relationships are built through these two way communication opportunities (Young, 2010).

The instantaneous contact with customers will lead to higher trust. Moorman, Zaltman \& Deshpande, (1992) defined trust as an element in which a person depends on his or her exchange partners whom he or she has 
confidence. Trust can bring many benefits in the relationships between marketers and their customers (Morgan \& Hunt, 1994) Customers can witness confidence, honesty and competence of their marketers (Ganesan, 1994; Donney \& Cannon, 1997). To be able to provide the products or service instantaneously can be considered the competence of the marketers in which the customers can trust. Therefore, It is likely that the customers will return to purchase more products with the marketers. Marketers can depend on customer's trust to guard the competitor's offers, bringing more sales to the company and creating brand loyalty eventually. Trust and brand loyalty are significant for the company to build a sustainable relationship with customers.

\section{DISCUSSION}

The attempt to offer the best for customers is always a big effort of investment in a corporation. One of the continuous investments is technologies which would connect marketers with the customers in real time, thereby offering services whenever and wherever they want.

Instantaneous marketing helps companies in various ways.

\section{To solve customer's problems}

To retain customers for the long run, salespersons know the fact that they must not try to sell the products alone without solving customer's problems. (Rosenberg \& Czepiel, 1984). The competition among companies to offer the best service to customers calls for a faster and more responsive service. Customers are facing with more choices which enhance their convenience, while corporations which provide a fast service would enhance their performance by offering much faster services to be ahead of their rivals. For instance, the followings are the prices of Fedex for delivering 1 pound of package from New York to Los Angeles based mainly on delivery time.

Same day in shortest time possible. Call 1-800 Go-Fedex for availability and rate (Fedex Same Day ${ }^{\circledR}$ )

\begin{tabular}{ll}
\hline Tomorrow 8:00am (Fedex First Overnight $\left.{ }^{\circledR}\right)$ & USD95.81 \\
Tomorrow 10:30am (Fedex Priority Overnight $\left.{ }^{\circledR}\right)$ & USD60.00 \\
Tomorrow 3:00pm (Fedex Standard Overnight $\left.{ }^{\circledR}\right)$ & USD54.86 \\
Second day 10:30am (Fedex 2Day® A.M.) & USD29.22 \\
Second day 4:30pm (Fedex 2Day ${ }^{\circledR}$ ) & USD25.41 \\
Third day 4:30p,m (Fedex Express Saver $\left.{ }^{\circledR}\right)$ & USD19.35 \\
End of day 4 Business day (Fedex Ground $\left.{ }^{\circledR}\right)$ & USD8.66
\end{tabular}

(source: https://www.fedex.coom/ratefinder/standaline?method=getQuickQuote)

Certainly, Fedex has a pricing level which would enhance the margin of the delivery service by providing the fastest way possible for customers, while customers also weigh the value of Fedex against all its competitors. What certainly changes here is the new service in which Fedex has created to enhance the value of the existing ones, solving customer's problems through the faster package delivery. It is interesting to see the Fedex Same Day is a personalized version that Fedex offers for the highest margin and fastest means for customers. Moreover, one of the values that all customers will get is the delivery information i.e. ability for the customers to track a package.

\section{To differentiate itself from its competitors}

Instantaneous marketing offers differentiation which is a generic competitive advantage. The company would stand out in the eyes of the customers as it can offer the products or services that are so unique and cannot be provided by any one of its rivals.

\section{Value Enhancement}

Instantaneous marketing through instant offers, instant channels and instant communication is an obvious means to enhance customer perceived value. In a fiercely competitive environment, firms are often facing with 
limited ideas and concepts to develop new products. Besides, they are also facing with limited R\&D budget in doing so. Therefore, one of the best solutions is to enhance the value through what they learn from customer databases and accelerate the timing of their services. Some have decided to offer ubiquitous channels where their customers can get the products or services any time they want from long operating hours, to vending machines and the Internet, etc. Even though it is impossible for a firm to provide both the instant offers and instant channels, it is always possible to offer instant communication. Customers will feel closer to be connected at any time they would like to do so. At present, even if the company closes their communication channel, customers would seek various websites and social media to communicate to others. Therefore, it is extremely difficult for a firm to avoid contacting instantly with their customers.

\section{Brand Loyalty and Relationships}

In the overall picture, companies which provide instantaneous marketing hope their customers would have brand loyalty through the differentiation as none can offer the same. Brand loyalty would bring in constant flow of income to a corporation. This would follow by a sustainable long-term relationship between the company and its customers, defending the company from its rivals.

Instantaneous marketing would be the trend that corporations would pursue and invest in the long run. The trend can be spotted throughout the history. In the beginning, the company operates longer hours and goes to the customer's premises. When telephone started a two-way communication, marketers make use of telephone to enable customers to call in and solve their problems. However, in today's world, marketers explore the Internetrelated and social media technologies to service their customers in a cheaper and more convenient way. They are forced to be more active in building brands by being more "spontaneous, relevant and active". (Wheeler \& Katz, 2011, p.20).

It is very obvious in our daily life that instantaneous marketing is prevalent as marketers try to differentiate their offering to customers. To be able to react and respond to the needs of customers instantly requires the will and efforts of the marketers to explore what their customers needs and wants. The advancement of digital technologies and customer databases enable marketers to connect with their customers in real time, strengthening closer relationships between the marketers and customers and eventually resulting in stronger brand loyalty for the firm.

\section{AUTHOR INFORMATION}

Boonchai Hongcharu, Ph.D. is Dean of NIDA Business School, National Institute of Development Administration, Bangkok, Thailand. He teaches marketing and management information systems. His research interest includes integrated marketing communications, new communications technologies and corporate governance. He can be contacted at bhongcharu@hotmail.com

\section{REFERENCES}

1. Donney, P.M., \& Cannon, J.P. (1997). An examination of the nature of trust in buyer-seller relationships. Journal of Marketing. 61, 35-51

2. $\quad$ Farris, D.W., Bendle, N.T., Pfeiffer, P.E., \& Reibstein, D.J. (2010). Marketing Metrics: The Definitive Guide to Measuring Marketing Performance. Upper Saddle River, NJ: Pearson Education Inc.

3. Fletcher, K, Wheeler, C. \& Wright, J. (1990). The role and status of UK database marketing. The Quarterly Review of Marketing, Autumn, 7-14.

4. Ganesan, S. (1994). Determinants of long-term orientation in buyer-seller relationships., Journal of Marketing, 58, 1-19.

5. Gilbreath, B. (2010). The Next Evolution of Marketing. New York: McGraw-Hill.

6. https://www.fedex.coom/ratefinder/standaline?method=getQuickQuote

7. Kimmel, A.J. (2010). Connecting with Consumers: Marketing for New Marketplace Realities. Oxford: Oxford University Press.

8. $\quad$ Leboff, G. (2011). Sticky Marketing. London: Kogan Page. 
9. Moorman, C.G., Zaltman, G., \& Deshpande, R. (1992). Relationships between providers and users of marketing research: The dynamic of trust within and between organizations. Journal of Marketing Research. 29, 314-29.

10. Morgan, R.M., \& Hunt, S.D. (1994). The commitment-trust theory of relationship marketing. Journal of Marketing. 58, 20-38.

11. Rosenberg, L.J. \& Czepiel, J.A. (1984). A marketing approach for customer retention. Journal of Consumer Marketing, 1, 45-51.

12. Ross, J.W., Weill, P. \& Robertson D.D. (2006). Enterprise Architecture as Strategy: Creating a Foundation for Business Execution. Boston: Harvard Business School Press.

13. Shostack, G.L. (1985). Planning the service encounter. In J.A. Czepiel, M.R. Solomon \& C.F. Surprenant. (Eds.). The Service Encounter, Lexington Books, pp. 243-53.

14. Solis, B. (2011). Engage! Hoboken, NJ: John Wiley and Sons, Inc.

15. Songini, M.L. (2001). "NBA shoots for data analysis" Computerworld. May 28.

16. Wheeler, A. \& Katz, J. (2011). Brand Atlas. Hoboken, NJ: John Wiley and Sons, Inc.

17. Young, A. (2010). Brand Media Strategy: Integrated Communication Planning in the Digital Era. New York: Palgrave Macmillan. 


\section{NOTES}

